\title{
PENERAPAN MODEL PROJECT BASED LEARNING GUNA MENINGKATKAN KETERAMPILAN REPRESENTASI MATEMATIS PESERTA DIDIK KELAS IV
}

\author{
Nur Hanifah*, Henny Dewi Koeswanti, Tri Sadono \\ Program Studi Pendidikan Profesi Guru Sekolah Dasar, Fakultas Keguruan dan Ilmu Pendidikan, Universitas \\ Kristen Satya Wacana. Jalan Diponegoro No. 52-60, 50711, Indonesia. \\ Email : 952020512@student.uksw.edu
}

\section{Article History}

Received : April 05 $5^{\text {th }}, 2021$

Revised : April 10 $10^{\text {th }}, 2021$

Accepted : May 05 ${ }^{\text {th }}, 2021$

Published : May 09 ${ }^{\text {th }}, 2021$

\begin{abstract}
Abstrak: Penelitian ini dilatarbelakangi oleh hasil observasi, wawancara dan tes pratindakan yang menunjukkan rendahnya keterampilan representasi pada kondisi awal dengan persentase sebesar $11.5 \%$ secara klasikal. Tujuan dari penelitian ini adalah meningkatkan keterampilan representasi peserta didik dengan menerapkan model pembelajaran Project Based Learning. Subjek penelitian terdiri dari 26 peserta didik kelas IV SDN Kauman Kidul Salatiga Tahun Ajaran 2020/2021. Jenis Penelitian yang dilaksanakan adalah Penelitian Tindakan Kelas (Classroom action research) dengan model Kemmis dan Mc Taggart. Penelitian tindakan ini dilaksanakan dalam dua siklus. Prosedur yang digunakan meliputi empat tahapan yaitu perencanaan tindakan, pelaksanaan tindakan, observasi dan refleksi. Teknik pengumpulan data yang digunakan dalam penelitian ini berupa tes, observasi, wawancara dan dokumentasi serta analisis data dengan model analisis interaktif Miles Huberman yang berisikan empat langkah yaitu pengumpulan data, reduksi data, verifikasi dan penyajian data. Kondisi awal keterampilan representasi di kelas IV menunjukkan hasil persentase sebesar $11.5 \%$ secara klasikal. Siklus pertama diawali dengan pembelajaran pertama setelah diterapkannya model project based learning yang menghasilkan presentase terampil sebesar $39,1 \%$ secara klasikal pembelajaran kedua $68.2 \%$ secara klasikal. Penelitian dilanjutkan dengan siklus ke dua yang telah mengalami peningkatan dengan hasil keterampilan representasi sebesar $86.36 \%$ dan pembelajaran ke dua sebesar 90\%. Tindakan yang telah dilakukan dalam setiap siklus mengalami peningkatan persentase pencapaian keterampilan representasi. Dengan demikian penerapan model pembelajaran Project Based Learning dapat meningkatkan keterampilan representasi. Model pembelajaran Project Based Learning cocok digunakan dalam pembelajaran matematika pada materi bangun datar khususnya untuk meningkatkan keterampilan representasi.
\end{abstract}

Kata kunci: Representasi, Project Based Learning

\section{PENDAHULUAN}

Keterampilan representasi merupakan salah satu dari lima standar proses yang harus dicapai dalam pembelajaran matematika yang telah ditetapkan oleh National Council of Teachers of Mathematics (National Council of Teacher of Mathematics (NCTM), 1989). Kompetensi dasar matematika pada kurikulum 2013 yang mengandung makna representasi tercantum pada Permen No. 68 Tahun 2013 yaitu "mencoba, merangkai, memodifikasi, mengolah dan menyaji dalam ranah konkret dan ranah abstrak sesuai dengan yang dipelajari di sekolah dan sumber lain yang sama dalam sudut pandang/teori”. Rangkuti, 2013 mendefinisikan Keterampilan representasi sebagai cara penyajian bentuk atau gambaran suatu masalah matematika yang harus diterjemahkan dalam bentuk tertentu.
Bentuk penyajian permasalahan dalam representasi dapat berupa kalimat, simbol, persamaan matematis dan gambar (Kartini 2009; Armadan., et al: 2017). Penyajian permasalahan tersebut digunakan sebagai alat bantu yang untuk menemukan solusi dari suatu permasalahan. Berdasarkan hasil pengamatan yang dilaksanakan pada tanggal 18 Januari 2021 di SDN Kauman Kidul Salatiga diketahui bahwa ada beberapa hal yang mempengaruhi rendahnya representasi matematis diantaranya adalah ada beberapa model dan metode yang kurang efektif dalam melaksanakan pembelajaran matematika. Penyampaian materi pembelajaran matematika pada saat daring khususnya dalam soal cerita guru lebih banyak menggunakan metode pemberian tugas. Banyak peserta didik yang belum mampu untuk merepresentasikan jawaban berbagai soal cerita karena mereka belum 
dilibatkan secara langsung dalam kegiatan representasi.

Keterampilan representasi soal cerita di sekolah dasar masih tergolong rendah karena peserta didik masih banyak peserta didik yang memiliki stigma negatif terhadap pembelajaran matematika. Terlebih lagi pembelajaran matematika berkenaan dengan dengan ideide/konsep abstrak yang tersusun secara hirarkis dan penalaran deduktif. Hal itu menyebabkan banyak peserta didik yang belum bisa menyajikan kembali permasalahan yang ada dalam soal cerita tersebut dalam bentuk tabel, gambar, kata-kata (teks tertulis), maupun dalam bentuk ekspresi matematis (Rangkuti, 2013). Berdasarkan hasil pengamatan yang dilakukan oleh peneliti di kelas IV pada tanggal 18 Januari 2021 peneliti mengamati pembelajaran di WA group beberapa peserta didik cukup antusias dalam mengerjakan tugas soal cerita, tetapi masih banyak peserta didik yang belum bisa memahami serta menjawab soal cerita yang diberikan guru. Menurut hasil pengamatan peneliti masih banyak peserta didik yang belum bisa merepresentasikan (menyajikan kembali) soal tersebut ke dalam gambar maupun kalimat matematika.

Berdasarkan hasil analisis keterampilan representasi soal cerita yang diperoleh dari hasil Ujian Akhir Semester peserta didik kelas IV menyatakan hanya 3 dari 26 peserta dengan persentase $11.5 \%$ dari keseluruhan siswa yang terampil dalam keterampilan representasi soal cerita. Hal tersebut membuktikan bahwa keterampilan representasi peserta didik di kelas IV masih tergolong rendah.

Peneliti memilih model Project Based Learning didasarkan pada syntax model yaitu tahap memonitor peserta didik dan kemajuan proyek, pada tahap ini peserta didik diharapkan untuk bisa merekonstruksi pengetahuannya sendiri melalui tahapan membuat proyek yang kemudian akan dikomunikasikan pada tahap menguji hasil kepada teman temannya dan selanjutnya siswa menyajikan hasil dari kedua tahap tersebut direpresentasikan dengan menulis pada tahap terakhir yaitu mengevaluasi pengalaman (Aris, 2014; Huda, 2013; Dedi 2020).

Hal tersebut diperkuat dengan adanya penelitian dari Ariani, 38-57: 2017 dengan hasil analisis penelitian diperoleh yaitu: (1) peningkatan kemampuan representasi matematis siswa yang menerapakan model pembelajaran berbasis proyek (Project Based Learning) lebih tinggi daripada siswa yang menerapkan pembelajaran biasa. Berdasarkan hasil penelitian, maka tujuan penelitian ini meningkatkan keterampilan representasi peserta didik pada soal cerita bangun datar dengan penerapan model pembelajaran Project Based Learning.

\section{METODE}

Penelitian tindakan dilaksanakan di SD Negeri Kauman Kidul Tahun Ajaran 2020/2021. Penelitian ini menggunakan pendekatan kualitatif dan kuantitatif dengan jenis Penelitian Tindakan Kelas (Classroom action research) dengan model Kemmis dan Mc Taggart. Subjek dalam penelitian ini adalah peserta didik di kelas IV SD Negeri Kauman Kidul Tahun Ajaran 2020/2021. Teknik pengumpulan data yang digunakan dalam penelitian ini berupa tes, observasi dan dokumentasi (Arikunto: 2013. Analisis data penelitian dilaksanakan model analisis interaktif Miles Huberman yang berisikan empat langkah yaitu pengumpulan data, reduksi data, verifikasi dan penyajian data dengan (Mu'alimin, 2018; Arikunto, 2013)

Penelitian tindakan ini dilaksanakan dalam dua siklus. Prosedur yang digunakan meliputi empat tahapan yaitu perencanaan tindakan, pelaksanaan tindakan, observasi dan refleksi. Berikut ini merupakan kategorisasi penilaian keterampilan representasi.

Tabel 1. Kategorisasi Penilaian Keterampilan Representasi Matematis

\begin{tabular}{cccc}
\hline No & $\begin{array}{c}\text { Interval } \\
\text { Persentase }\end{array}$ & $\begin{array}{c}\text { Interval } \\
\text { Skor }\end{array}$ & Kategori \\
\hline 1. & $>88.5 \%$ & $>45$ & $\begin{array}{c}\text { Sangat } \\
\text { Terampil }\end{array}$ \\
\hline 2. & $77 \%-88.5 \%$ & $39-45$ & Terampil \\
\hline 3. & $64.5 \%-76 \%$ & $33-38$ & $\begin{array}{c}\text { Kurang } \\
\text { Terampil }\end{array}$ \\
\hline 4. & $<63 \%$ & $<33$ & $\begin{array}{c}\text { Tidak } \\
\text { Terampil }\end{array}$ \\
\hline
\end{tabular}

$$
\begin{aligned}
\text { Rentang Predikat } & =\frac{\text { nilaimaksimum }- \text { KKM }}{2} \\
& =\frac{100-77}{2}=11,5
\end{aligned}
$$

Penelitian ini memiliki indikator kinerja $80 \%$ dari keseluruhan peserta didik yang hadir mendapat $\geq 77$ serta setiap aspek harus mendapat skor $>1$ dalam keterampilan representasi. Kategori dalam penelitian ini dibagi menjadi 4 yaitu sangat terampil, terampil, kurang terampil, dan tidak terampil. Indikator kinerja penelitian akan tercapai apabila terdapat $80 \%$ dari 
keseluruhan peserta didik yang hadir terampil dalam keterampilan representasi (berada dalam kategori terampil dan sangat terampil).

\section{HASIL DAN PEMBAHASAN}

Peningkatan keterampilan representasi peserta didik ditunjukkan oleh data hasil penelitian yang terdiri dari tiga sajian data. Penyajian data tersebut terdiri dari data pratindakan, siklus I dan siklus II.

\section{Hasil Penilaian Keterampilan Representasi Matematis Bangun Datar Pratindakan}

Hasil penelitian menunjukkan bahwa sebelum penerapan model pembelajaran Project Based Learning diperoleh simpulan bahwa keterampilan representasi pada soal cerita bangun datar masih rendah. Berikut data pratindakan dipaparkan dalam Gambar 1.

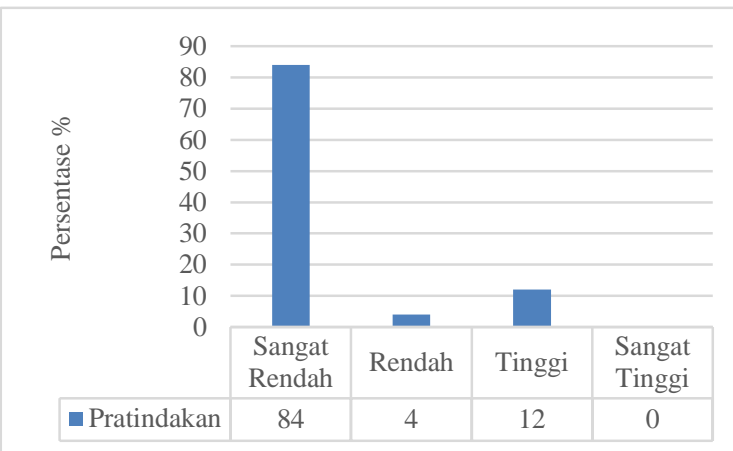

Gambar 1. Hasil Keterampilan Representasi

Matematis Bangun Datar Pratindakan

Gambar 2. merupakan penjelasan hasil dari keterampilan representasi matematis sebelum diterapkannya model pembelajaran Project Based Learning yang masih tergolong dalam kategori sangat rendah dengan persentase sebesar $84 \%$ pada kategori sangat rendah, sebesar $4 \%$ pada kategori rendah dan sebesar $12 \%$ pada kategori tinggi, dan sebesar $0 \%$ pada kategori sangat tinggi.

\section{Hasil Penilaian Keterampilan Representasi Matematis Bangun Datar Siklus I}

Hasil penelitian setelah diterapkannya model pembelajaran Project Based Learning diperoleh bahwa keterampilan representasi pada soal cerita bangun datar mengalami peningkatan pada siklus I. berikut penyajian data siklus I dapat dilihat pada Gambar 2.

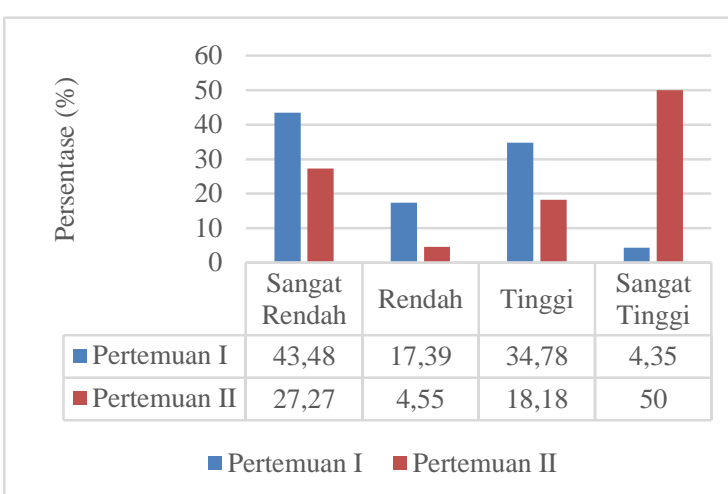

Gambar 2. Hasil Keterampilan Representasi Matematis Bangun Datar Siklus I

Gambar 2. merupakan penjelasan hasil dari keterampilan representasi matematis setelah diterapkannya model pembelajaran Project Based Learning. Pembelajaran pertama menunjukkan hasil persentase $39 \%$ peserta didik yang terampil sebesar (kategori tinggi sebesar $34.78 \%$, kategori sangat tinggi sebesar $4.35 \%$ ) sedangkan persentase peserta didik yang belum terampil sebesar $51 \%$ ( kategori sangat rendah sebesar $43.48 \%$, kategori rendah sebesar $17.39 \%$ ). Pertemuan kedua persentase peserta didik yang terampil sebesar $68.18 \%$ (kategori tinggi sebesar $18.18 \%$, kategori sangat tinggi sebesar 50\%), sedangkan persentase peserta didik yang belum terampil sebesar $31.82 \%$ (kategori sangat rendah sebesar 27.27\%, kategori rendah sebesar 4.55\%). Walaupun telah terjadi peningkatan dari pratindakan ke siklus I namun belum mencapai target indikator kinerja penelitian sebesar $80 \%$. Penelitian dilanjutkan ke siklus II sebagai perbaikan dari siklus I dengan merefleksi kekurangan yang ada pada siklus I sehingga dapat diperbaiki pada siklus II.

\section{Hasil Penilaian Keterampilan Representasi Matematis Bangun Datar Siklus II}

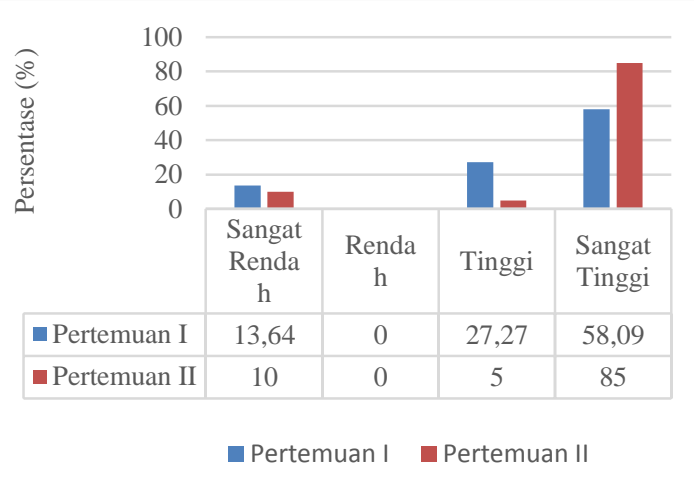

Gambar 3. Hasil Keterampilan Representasi Matematis Bangun Datar Siklus II 
Gambar 3. menjelaskan hasil dari keterampilan representasi bangun datar setelah diterapkannya model pembelajaran Project Based Learning pada pertemuan pertama menunjukkan persentase peserta didik yang terampil sebesar $86.36 \%$ (kategori tinggi sebesar $27.27 \%$, kategori sangat tinggi sebesar 58.09\%) sedangkan persentase peserta didik yang belum terampil sebesar $13.64 \%$ (kategori sangat rendah sebesar $13.64 \%$, kategori rendah sebesar 0\%). Pertemuan kedua persentase peserta didik yang terampil sebesar $90 \%$ (kategori tinggi sebesar 5\%, kategori sangat tinggi sebesar 85\%), sedangkan persentase peserta didik yang belum terampil sebesar $10 \%$ (kategori sangat rendah sebesar 10\%, kategori rendah sebesar 0\%). Peningkatan pada siklus II telah mencapai target indikator penelitian sebesar $80 \%$.

\section{Pembahasan}

Berdasar data yang telah diuraikan pada deskripsi data terjadi peningkatan pada keterampilan representasi dari siklus I ke siklus II telah mencapai target indikator kinerja penelitian. Peningkatan kinerja guru dan aktivitas peserta didik juga berbanding lurus dengan peningkatan keterampilan representasi. Perbandingan hasil analisis indikator keterampilan representasi pada soal cerita bangun datar pratindakan, siklus I dan siklus II disajikan dalam tabel 1. berikut :

Tabel 1. Perbandingan Hasil Penilaian Keterampilan Representasi Matematis Bangun Datar Antar Siklus

\begin{tabular}{llccccc}
\hline & & \multicolumn{2}{c}{$\begin{array}{c}\text { Pra } \\
\text { No }\end{array}$} & Keterangan & Siklus I & \multicolumn{2}{c}{ Siklus II } \\
\cline { 2 - 7 } & \multicolumn{4}{c}{ Pert. 1 Pert. 2 } & Pert. 1 & Pert. 2 \\
\hline \multirow{2}{*}{1} & $\begin{array}{l}\text { Skor } \\
\text { Terendah }\end{array}$ & 4 & 8 & 4 & 18 & 20 \\
\hline 2 & $\begin{array}{l}\text { Skor } \\
\text { Tertinggi }\end{array}$ & 85 & 96 & 94 & 100 & 100 \\
\hline 3 & $\begin{array}{l}\text { Skor Rata- } \\
\text { rata }\end{array}$ & 31.07 & 58.11 & 66.3 & 84.35 & 89.46 \\
\hline 4 & $\begin{array}{l}\text { Ketercapaian } \\
(\%)\end{array}$ & $11.5 \%$ & $39.1 \%$ & $68.2 \%$ & $86.36 \%$ & $90 \%$ \\
\hline
\end{tabular}

Data yang terdapat pada tabel 1. menunjukkan adanya peningkatan keterampilan representasi peserta didik antar siklus. Skor terendah dan juga skor tertinggi yang bersifat fluktuatif karena mengalami kenaikan dan penurunan nilai. Skor rata-rata tiap pertemuan dari pertemuan I siklus I sampai pertemuan II siklus II mengalami kenaikan yang cukup pesat. Selanjutnya untuk persentase ketercapaian mengalami peningkatan dari siklus I ke siklus II . Peningkatan persentase ketercapaian tersebut telah memenuhi target indikator kinerja penelitian pada siklus II sebesar $90 \%$.

Peningkatan tersebut terjadi karena pengaruh kinerja guru dan aktivitas guru dalam melaksanakan kegiatan pembelajaran menggunakan model Project Based Learning serta mampu mengatasi hambatan yang terjadi sehingga pembelajaran dapat berlangsung secara efektif dan efisien. Kesulitan yang dialami guru pada saat mengaplikasikan model Project Based Learning salah satunya pada tahapan menyusun perencanaan proyek (design project) yakni guru belum bisa sepenuhnya mengajak seluruh peserta didik untuk berkolaborasi merencanakan proyek karena dalam kondisi daring serta fasilitas peserta didik yang belum memadai cukup sulit untuk mengadakan pembelajaran secara sinkronus. Selain itu masih ada kesulitan guru pada tahapan memantau siswa dan kemajuan proyek (monitoring the students and progress of project) terkadang ada beberapa peserta didik yang tidak mengirimkan proses pembuatan proyek sampai batas waktu yang diperlukan. Kesulitan-kesulitan tersebut merupakan kesulitan umum yang terjadi pada setiap siklus.

Upaya yang dapat dilaksanakan guru saat pembelajaran dengan mengaplikasikan model Project Based Learning agar pembelajaran efektif dan efisien merupakan perbaikan pada tahap menyusun perencanaan proyek (design project) dilaksanakan dengan cara berdiskusi menggunakan whatsapp pada hari sebelum proyek sehingga sebagian besar peserta didik dapat ikut berkolaborasi dalam merencanakan proyek. Selanjutnya pada tahapan memantau siswa dan kemajuan proyek (monitoring the students and progress of project) guru bisa mengajak peserta didik untuk berkomitmen apabila belum mengumpulkan tugas sampai batas waktu tertentu maka akan ada sanksi yang diberikan, selain itu guru juga dapat mengingatkan peserta didik untuk segera mengumpulkan video pembuatan proyek. Adanya solusi tersebut diharapkan pada siklus berikutnya peserta didik dapat melaksanakan pembelajaran dengan lebih baik lagi.

Hasil observasi aktivitas peserta didik pada setiap tahapan berbanding lurus dengan kinerja guru yang berakibat pada hasil evaluasi keterampilan representasi peserta didik yang cenderung meningkat. Berdasar uraian data yang telah diperoleh terdapat peningkatan keterampilan representasi pada siklus I dan siklus II. Sehingga dapat disimpulkan bahwa penerapan 
model Project Based Learning dapat membantu meningkatkan keterampilan representasi matematis pada materi bangun datar kelas IV SD Negeri Kauman Kidul Tahun Ajaran 2020/2021.

\section{KESIMPULAN}

Berdasarkan hasil dari penelitian yang telah diuraikan, maka dapat dinyatakan bahwa penelitian ini dapat meningkatkan keterampilan representasi peserta didik di kelas IV SD Negeri Kauman Kidul Tahun Ajaran 2020/2021. Hal tersebut dapat dibuktikan dengan fakta-fakta yang diperoleh dari hasil penelitian di lapangan bahwa persentase ketercapaian keterampilan representasi peserta didik meningkat hingga mencapai indikator kinerja penelitian. Sehingga, dapat dikatakan bahwa penerapan model Project Based Learning dapat meningkatkan keterampilan representasi peserta didik.

\section{UCAPAN TERIMA KASIH}

Alhamdulillahi rabbil'alamin segala puji syukur penulis panjatkan kepada Allah Subhanahu Wa Ta'ala sehingga penelitian dapat berjalan dengan baik dan lancar. Penulis menyadari bahwa penelitian ini dapat selesai dengan bantuan, bimbingan, dan pengarahan dari berbagai pihak. Penulis menyampaikan terima kasih kepada Ibu Nanik Sri Wahyuningsih dan Bapak Hariyanto Atas segala do'a yang telah dipanjatkan, bimbingan dan dukungan luar biasa yang selalu menyertai dalam melaksanakan penelitian. Terimakasih atas bimbingan dari Dr. Henny Dewi Koeswanti, M.Pd., Tri Sadono, S.Pd., M.Pd, Yulianti, S.Pd. dan peserta didik kelas IV SDN Kauman Kidul yang membantu dalam pelaksanaan penelitian ini.

\section{REFERENSI}

Ariani, Nurlina (2017). "Peningkatan Kemampuan Representasi Matematis dan Motivasi Belajar Siswa melalui Model Pembelajaran Berbasis Proyek (Project Based Learning) di Kelas VII SMP Negeri 1 Torgamba Tahun Pelajaran 2016/2017." Jurnal Pembelajaran dan Matematika Sigma, 3 (1), Mei 2017, hal $38-47$

Arikunto, S. (2013). Metodologi Penelitian. Jakarta: Rineka Cipta
Aris Shoimin (2014). "68 Model Pembelajaran Inovatif Dalam Kurikulum 2013." Yogyakarta: Ar Ruzz Media.

Armadan, Armadan, Somakim Somakim, \& Indaryanti Indaryanti. (2017). "Kemampuan Representasi Matematis Siswa Pada Pembelajaran Berbasis Teori Van Hiele Di Materi Segiempat Kelas VII SMP Negeri 1 Indralaya Utara." Jurnal Elemen 3(1):49. doi: 10.29408/jel.v3i1.306.

Dedi Kristiyanto (2020). Peningkatan Kemampuan Berpikir Kritis dan Hasil Belajar Matematika dengan Model Project Based Learning (PJBL). Jurnal Mimbar Ilmu. 25 (1)

Direktorat Jenderal Pendidikan Dasar dan Menengah Kementerian Pendidikan dan Kebudayaan (2016). "Panduan Penilaian Untuk Sekolah Dasar (SD)."

Huda, Miftakhul (2013). Model-model Pengajaran dan Pembelajaran. Yogyakarta: Pustaka Pelajar.

Imawan, O R. (2015). Perbandingan Antara Keefektifan Model Guided Discoveri dan Project Based Learning pada Mata Kuliah Geometri. Pythagoras: Jurnal Pendidikan Matematika, 10(2), 179-188,

Jitedra, Asha., et al. (2016). "Is Mathematical Representasion Of Problems An Evidence Based Strategy For Students With Mathematics Difficulties? Exceptional Children", 83 (1), 8-25,

Kartini (2009). "Peranan Representasi Dalam Pembelajaran Matematika." Pp. 361-72 in Seminar Nasional Matematika dan Pendidikan Matematika UNY.

Mu'alimin (2018). Classroom Action Research. Pasuruan: Gading Pustaka.

National Council of Teacher of Mathematics (NCTM) (1989). "Curriculum and Evaluation Standards for Schools Mathematics."

Rangkuti, Ahmad Nizar (2013). "Representasi Matematis." Logaritma VI (01 Januari) 
Nur Hanifah et al. (2021). Jurnal Ilmiah Profesi Pendidikan, 6 (1): 54 - 59

DOI: https://doi.org/10.29303/jipp.v6i1.147

:110-27.

Sabirin, Muhamad (2014). "Representasi Dalam Pembelajaran Matematika." Journal Pendidikan Matematika 01(2):33-34.

Tampubolon, S. (2014). Penelitian Tindakan Kelas Sebagai Pengembangan Profesi Pendidik dan Keilmuan. Jakarta.
Wulandari, F E. (2016). Pengaruh Pembelajaran Berbasis Proyek Untuk Melatih Keterampilan Proses Mahasiswa. Jurnal Pedagogia, 5(2), 247-254, 2016. 